\title{
$\mathrm{PH} 101_{\text {debate }}$
}

a debate Hacia una nueva institucionalidad cultural. Modelos emergentes de gestión...

| coordina Jesús Carrillo Castillo

\section{Arte y salud, las prescripciones museales, una forma innovadora de superar la pandemia}

\author{
Gabriela Sánchez | Universidad de Ottawa. Canadá \\ URL de la contribución <www.iaph.es/revistaph/index.php/revistaph/article/view/4763>
}

De manera general el alcance e implicaciones de las estrategias que se emplean en proyectos museales, conllevan tradicionalmente la idea de un público que deambula por sus espacios interiores. Sin embargo las nuevas formas de inclusión participativa permiten la interacción multidisciplinar e incluyen al público como generador de acciones de arte. Es de este modo, que el M. de B. Artes de Montreal junto a los miembros de la salud ha dado un giro participativo prescribiendo el arte como forma terapéutica. A partir de este proyecto del Museo de Bellas Artes de Montreal se busca explorar las estrategias metodológicas de instituciones, artistas, activistas, médicos, ciudadanos y agentes culturales; que transforman los modos de participación en el arte . Asimismo interesa el impacto que producen en la comunidad estos métodos "alternativos" que involucran arte, salud bajo la mirada del público como un "todo integral". Cuestionamos la manera en que estos sistemas multidisciplinarios se integran o se alejan del concepto democratizador de las instituciones museales. Qué pueden aprender las instituciones culturales al interactuar con otros agentes culturales y terapeutas. Cuáles son las resistencias o tensiones que se producen en los sujetos que se hallan atravesados discursivamente por miradas de salud y arte al mismo tiempo. Los conceptos de globalización/desglobalización (GARCÍA CANCLINI, 2020: 11), sirven para entender las problemáticas locales 0 globales de doble direccionamiento. Igualmente consideramos valioso abordar el concepto de políticas de la mirada (RICHARD, 2007), el cual interesa para nutrir y permitir el debate sobre qué y cómo miramos y somos mirados.

Al hablar de instituciones museales tenemos que indefectiblemente aceptar las diversas interpretaciones que de lo patrimonial se realiza en la actualidad. El concepto

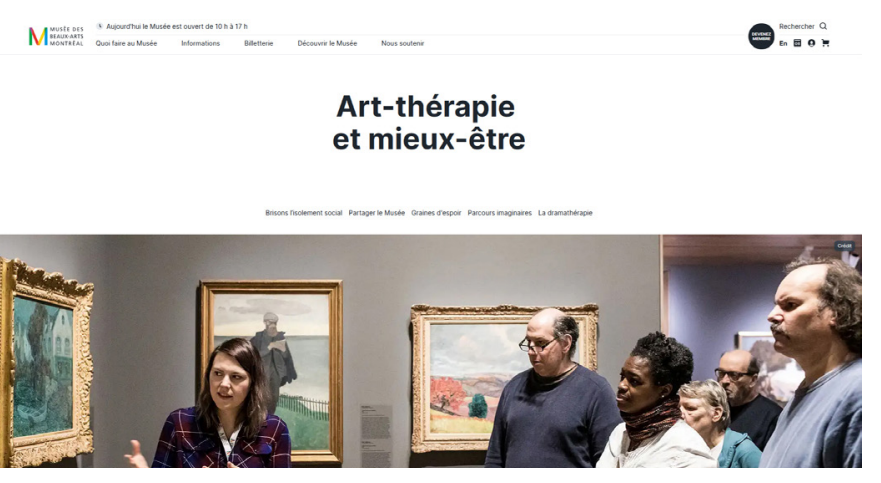

mismo de patrimonio, como establece Françoise Choay, "es una concepto 'nómada', y paralelamente erige nuevos y diversos lenguajes patrimoniales" (CHOAY, 1992: 68). Ciertamente esta capacidad dinámica y transformativa del campo de lo museal y sus diversos lenguajes demuestra que la evolución de lo patrimonial se expande desde lo global a lo local en procesos de ida y vuelta. En la actualidad no podemos seguir considerando las estrategias museales "como recursos performativos que programaban el comportamiento de los visitantes" (BENNETT, 2004: 10) . Por el contrario, se evidencia en este proyecto en particular, la búsqueda de un visitante activo y participe que produzca su propio recorrido de apropiación del espacio de arte y del arte mismo.

En las nuevas políticas los museos o espacios patrimoniales intentan comportarse, en diversas oportunidades, como espacios a-políticos y neutros frente a los impactos de las políticas institucionales globales, locales o glocales en las que se hallan inmersos. Es imposible analizar el comportamiento institucional de un espacio museal sin considerar lo político atravesando sus discursos. De cara a las nuevas tecnologías y procesos de dinamización de las instituciones museales se pro- 
ducen una serie de acciones tendientes a la "democratización" de los espacios museales. ¿Podemos hablar de una "democratización" en un espacio no politizado? Frente a esta interrogante sustentamos que no existen instituciones museales o patrimoniales cuyos procederes y acciones se desvinculen de políticas culturales que rigen, directa o indirectamente, sus decisiones. Estas instituciones elaboran e implementan discursos patrimoniales $\mathrm{y}$, paralelamente, los mismos generan políticas discursivas verticalizadas que definen las posiciones de público por una parte y de generadores de contenido por otra, como roles fijos e inamovibles.

En este contexto, el proyecto del Museo de Bellas Artes de la ciudad de Montreal ha desarrollado una iniciativa que permite horizontalizar y subvertir, en algunos casos, las posiciones de público pasivo versus generador de contenido. $Y$ asimismo, se fundan nuevos intercambios interdisciplinarios que amplían el horizonte de estos roles tradicionalmente estáticos. Las "prescripciones museales" revalorizan una serie de dispositivos democratizadores que rompen con las presunciones de un público consciente de su rol pasivo. Por el contrario, estos participantes del museo se apropian de ese espacio y se transforman en productores de arte. Los talleres en los cuales participan conllevan la concientización de su participación activa y sus obras son creaciones marcadas por la fuerza que se produce al ser protagonista. Las "prescripciones museales" son la toma de consciencia, por parte de las autoridades médicas, de un compromiso con el ser humano en su integridad permitiendo la conexión del mismo con el arte, bajo la clara visión de los beneficios que otorga. Esta serie de relaciones interdisciplinarias, médicos, agentes culturales e instituciones promueve dentro de los espacios patrimoniales, una verdadera apropiación de los mismos por parte de un participante activo. Es lo que Nelly Richard establece como fronteras dinámicas entre el arte y el no arte, "una nueva constelación expandida de lo visual que abarca todas las formas de ver, de ser visto y de mostrar" (RICHARD, 2007: 96).

Estas tendencias permiten asimismo cuestionar la posición de las instituciones frente a la "cultura" y sus diver- sas interpretaciones e interpelaciones. Entendemos aquí que no hay una sola manera de definir la cultura y preferimos hablar de culturas. Lo cultural de una institución museal parece estar en su misma fundación, sin embargo cuando concebimos estas "prescripciones de arte" como una acción cultural, asumimos que este concepto de cultura es polisémico y sujeto a las dinámicas sociales. Lo mismo sucede con el arte y su valorización social, las cuales actualizarán "sus criterios de distinción según las formaciones culturales en las que institucionalmente se generan" (RICHARD, 2007: 100). Estas diferentes formas de acción multidisciplinaria generan múltiples y variadas miradas, lo que valoriza las diversas aproximaciones que de las "prescripciones museales" podemos realizar. Médicos, terapeutas artísticos y espacios de creación, acercan a la institución museal a las problemáticas de la comunidad. Son formas creativas e innovadoras que permiten reivindicar el valor social del arte y rejerarquiza a la institución museal, no como una jerarquía vertical y autoritariamente impuesta sino como un accionar democráticamente institucionalizado.

\section{BIBLIOGRAFÍA}

- BENNETT, T. (2004) Pasts beyond Memory: Evolution Museums Colonialism. Museum Meanings. London; New York: Routledge. 2004

- CHOAY, F. (1992) L'allégorie Du Patrimoine. Paris: Editions du Seuil, 1992

- GARCÍA CANCLINI, N. (2020) Ciudadanos Reemplazados Por Algoritmos. Bielefeld: Transcript, 2020 (Colección CALAS 9)

- RICHARD, N. (2007) Estudios visuales, políticas de la mirada y crítica de las imágenes. En Fracturas de la memoria. México: FCE, 2007, pp. 95-106 